\title{
Party-Komsomol Relations in the Soviet Military, 1918-1924 Andrew Juricic
}

\begin{abstract}
During the Russian Civil War many Communist Youth League (Komsomol) military recruits loyally supported the Bolshevik Party on the civilian and military fronts. With the cessation of hostilities the Komsomol attempted to consolidate control over its members in the armed forces by creating Komsomol military cells. Party leaders, helieving that Komsomol recruits were politically unreliable, denied all Kornsomol requests for autonomy and forced League members to subordiante themselves to military Party organs and to undergo intensive political indoctrination. The Party hoped that these measures would raise the political qualifications of Komsomol recruits. As the number of Komsomol members in military units grew, the strict subordination of Komsomol members proved untenable. "The Party therefore created Komsomol "groups assisting che Party" in 1924. Their establishment effectively purged the Party of politically immature Komsomol members and reorganized the Party's military control apparatus.
\end{abstract}

In the late 1850s and early 1860s Russia's youths established several revolutionary organizations aimed at toppling Tsarism. Among these groups were The Circle of Kazan Students at Moscow University and Young Russia. Because these groups played an important role in the radical politics of the late nineteencl cencury, support of these young militants was a crucial part of the platform of most revolutionary parties. To the chagrin of their socialist opponents, including the Socialist Revolutionaries and Mensheviks, the Bolsheviks became the sole patron of Russia's revolutionary youths with the establishment of the Russian Communist Youth League (Komsomol) ${ }^{1}$ in 1918. At the Komsomol's first conference, convened at the People's Commissariat of Enlightenment in Moscow from October 29 to November 4, the delegates declared that the League would be an independent organization dedicated to the interests of youths. Ideas of independence were quickly dashed, however, as it became clear that the Party intended, 
contrary to the wishes of many Komsomol delegates, that the League serve the exclusive interests of the Bolsheviks. ${ }^{2}$

In the face of constant attempts by the Party to manipulate the membership and agenda of the Komsomol, many Komsomolites at all levels of the organization, but usually in local cells, ${ }^{3}$ fought to divorce the League's work from the interests of the Party and establish the Komsomol as a truly independent organization. The struggle between the two organizations to shape the mandate of the League and control the Komsomol's membership became the hallmark of early Party-Komsomol relations. Although Party control of the Komsomol varied depending on the willingness of Komsomolites to stand up to Party members and on the perceived political reliability of certain Komsomolites, wich urban members usually receiving more accommodation than their rural counterparts, the Party always exercised some degree of control over the activities of the League. ${ }^{4}$

One arena in which the Party and the Komsomol competed for authority over local Komsomol members was in the Soviet military during and immediately after the Russian Civil War (1918-1920). Following the war the Komsomol attempted to control its members serving in the armed forces by establishing cells in military units. ${ }^{5}$ The Bolsheviks opposed such a move because they believed that Komsomol cells would infringe upon the authority of military Party organs and threaten Bolshevik control of the armed forces. Even though it was clear that many Komsomolites admirably served the Bolsheviks during the war the Party would not reevaluate its position. Instead, berween 1921 and 1924, the Parcy responded to the perceived challenge of the Komsomol by attempting to proletarianize and politically indoctrinate the League's military recruits. I ronically, in 1924 control over military Komsomol members required the Party to grant the Komsomol the increase in autonomy which it had been continually demanding for the previous three years. 
Soviet authors, led by Yuri Petrov, assert that this change in policy was due to the Soviet leadership's unqualified trust in Komsomol recruits and the fact that Komsomol autonomy would lead to increased political awareness among Komsomolites. ${ }^{6}$ Petrov and others make this claim and support the official Party position even when they provide contradictory evidence and illustrate the fallacy of Party propaganda. ${ }^{7}$ The available evidence, in fact, shows that contrary to Petrov's assertions, the Party did not trust Komsomol recruits at any time between 1918 and 1924. The Bolsheviks believed that the Komsomol's aspirations for autonomy jeopardized their authority in the military and therefore the Party continually attempted to impose strict control over recruits. Furthermore, the Party allowed the Komsomol to increase its autonomy only when the integrity of the Party was endangered and the direct control of Komsomol recruits had become both cumbersome and outdated.

Western studies of the Sovier military, including works by Michael Deane, Zbigniew Brzezinski, and Timothy Colton, ${ }^{8}$ focus on the development of political commissars into the Main Political Administration. Even Mark von Hagen's authoritative study of the Red Army in the 1920s and 30s neglects the role of the Komsomol in the armed forces and the struggle which characterized early Party-Komsomol relations. ' Because of a lack of available primary sources this paper is based on secondary Soviet sources. ${ }^{10}$ Despite the drawbacks of this approach and the limitations inherent in the sources, the material used has still provided a wealth of information and has enabled an analysis of the Party's attempts to control Komsomol recruits during and immediately following the Civil War.

Throughout the course of the Civil War the Komsomol Central Committee organized nine different mobilizations of its membership for various military ducies. Of these, the three most important were the All-Russian mobilizations in May and October 1919 and in March of the following year to the Eastern, Southern, and Polish fronts 
respecrively." During these three general mobilizations the Central Committee instructed each local cell to send a specific portion of its membership for military training and to the front with the warning that noncompliance with these orders would not be tolerated. ${ }^{12}$ The fear of punishment, perhaps even execution, for not fulfilling orders became the best incentive for reluctant Komsomol members to participate in Red Army units.

At the Second Komsomol Congress in October 1919 the Central Committee outlined, in detail, the regulations for the Second All-Russian mobilization. In six districts, Orlov, Tula, Voronezh, Ryazan, Tambov, and Kaluga, in the vicinity of the Southern front, organizations were to implement a general mobilization, i.e., all members were to be inducted into the armed forces. Outside these six areas, and excluding the Petrograd organization, cells were to mobilize 30 percent of their members who were over the age of sixteen, the minimum age for enlistment. The demand from the Red Army for more soldiers must have been steadily growing during the Civil War since, just five months earlier, during the First All-Russian Mobilization, the required number of members to be recruited had been set at only 20 percent.

A three-person commitcee composed of senior members from each cell was to conduct the moblization of members. Although members worked independently of outside interference they were instructed to report to Party committees and military commissars on their work. Once formed, the committee was given one week to commence recruitment of the designated number of Komsomol members from each cell and to have them report to Party and revolutionary committees for transport instructions. Following the completion of mobilization orders a Komsomol cell could continue to operate only if three active members were still present, which would not be the case when a general mobilization was ordered. ${ }^{13}$

The Second All-Russian mobilization also provided regulations for military-related activities. Komsomol 
directives ordered members who could not meet either the age or physical requirements for military duty to help in supply, communication, and sanitation work, unless their political qualifications were sufficient to permit them to work in agitation brigades. Orders also instructed female members to work as medical attendants and in other positions which were deemed suitable for women. The Bolshevik losses during the Civil War were apparently not so severe as to warrant the mobilization of women, a position which would result in the League's membership becoming effeminate. ${ }^{14}$ These organizational duties occupied a significant part of the Komsomol's Civil War efforts, and, for reasons explained below, have been the point on which Soviet authors have focused their analysis of the Komsomol's military activities.

According to various Soviet sources the numbers raised by these mobilizations range from 30,000 to 45,000 recruits. This large discrepancy reveals that Soviet propaganda has superseded Soviet scholarship. Many Soviet authors have pointed out that during the Civil War all the Komsomol members who joined the Red Army did so enthusiastically and without a thought for their personal safety. They also emphasize that the euphoria of the revolution inspired many members to volunteer for military service before the Komsomol Central Committee called for a general mobilization. Soviet authors claim that the secret enlistment of members is the reason for the numerical discrepancies. ${ }^{15}$ This explanation, however, cannot be accurate.

If Komsomol members were secretly enlisting en masse for military dury one must ask why it was necessary for the Komsomol Central Committee to conduct nine mobilizations for the war. Also, if members immediately volunteered for dury once a mobilization had been called, the recruitment of members through a mobilization committee would have been unnecessary. A more plausible scenario was that many Komsomol members were unwilling to volunteer for direct military service and were unresponsive to committees that were under the guidance and pressure of 
military commissars. While some urban Komsomol members wishing to imitate the heroism of the Red Guards may have volunteered to fight, it is extremely unlikely that rural Komsomol members, whose concerns were confined to the village limits, were willing participants in the Civil War.

Such exaggeration by Soviet authors can be illustrated in another way. In order to incorporate those members who had covertly fought behind enemy lines into the total for Komsomol participation in the war, these authors felt justified in raising the number to nearly 60,000 . If this number is correct, over 50 percent of the organization's membership in 1919 were mobilized to fight in the Civil War. ${ }^{16}$ Since many members were nor directly involved in military campaigns and would have preferred to work in food detachments and propaganda brigades than be enlisted in military units, this number is probably inflated. Unfortunately, since Soviet authors endlessly repeat these embellished figures it is difficult to estimate the exact number.

The preoccupation with numbers on the part of Soviet authors has led them to neglect an examination of the Komsomol's work in military divisions during the Civil War. One possible explanation for this lack of attention may be that Soviet authors have not wanted to reveal the strict control that Party organs exercised over Komsomol members in the ranks of the military. ${ }^{17}$ While this control may be explained as an understandable precaution with untested recruits, it was more likely the result of the Party's fear of allowing politically unreliable armed youths extensive freedom of movement and its desire to avoid challenges to the authority of the political officers arising from undisciplined recruits. As a result, Soviet authors focused on the more popular military-related activities of the Komsomol, which were much less controlled by Party functionaries because of their less belligerent and strategic nature. This deliberate misrepresentation of the facts has diverted attention from the issue of strict Party control over Komsomol recruits.

Military Komsomol members were subordinated to Party organs early in their training by means of compulsory 
general military education. In military courses instructors taught Komsomol members to use various firearms, to throw grenades and dig trenches, and to gather intelligence. Party members enrolled Komsomolites who were endowed with a muscular physique in classes for machine gunners, military technicians, and commanders. Although female members received military education together with their male counterparts, Party propagandists told them to fulfil medical, and nor direct military duties. ${ }^{18}$ If members did not complete their obligatory military training sessions, they were considered to have broken Komsomol discipline and were punished accordingly.

Besides military instruction, courses also focussed on political propaganda. Political discussions emphasizing the "military tradition of the working class," as well as films and lectures, occupied much of the instructional time of Komsomol members. Some of the most common subjects of political lectures and discussions were the creation of the Red Army, the resolutions of the Bolshevik Party, the biography of Lenin, and the unity of workers and the Red Army. ${ }^{19}$ Following classes, the Party instructed Komsomolites to teach the information which they had acquired during lectures to recently conscripted recruits. The Party also encouraged Komsomolites to collect money for purchasing books and other political literature. Military training, therefore, offered the Party the opportunity to indoctrinate Komsomol recruits and begin the process of subordinating them to military Party organs.

Following military education classes, Party committees registered Komsomol members for ducy on both the civilian and military front lines in the Civil War. One of the most important tasks assigned to Komsomol members was political agitation among both civilians and soldiers through the distribution of Bolshevik propaganda. The dissemination of propaganda was designed to bolster support for the Party and for the military effort. Constantly in contact with both the front lines and the rear, Komsomolites often coordinared the transportation of military materiel to and from the front 
and sent messages to soldiers from city Party organs and from their families. ${ }^{20}$ Komsomol members were also extremely active in the countryside, aiding the families of Red Army soldiers by helping them with farm work and supplying them with food and livestock. Although this philanthropical task would continue to be a part of the Komsomol's duties following the Civil War, it would become more regulated by the Party as the government tightened its hold on the countryside. $^{21}$

In the ciries Komsomol members were ardent supporters and promoters of the war effort. In reserve units Komsomol members rounded up deserters and stood guard at munition dumps and transport facilities and collected warm clothes and other goods for the soldiers. Komsomolites arranged special theatrical and musical performances and used the contributions to buy goods for the front. In factories they organized working Saturdays (subbotniki) and Sundays (voskresniki) and movements such as the "Week of the Front" to raise money for wounded soldiers and their families. Komsomol memberseven pressured factory workers to contribute part of their earnings and some of the factory's production for the soldiers at the front and for the war effort. They also persuaded workers to repair equipment efficiently, especially transport machinery crucial to the war effort. Komsomol members called upon women to knit clothes for soldiers and comfort them during their recuperation in hospitals. ${ }^{22}$ Allowed grearer independence than their counterparts in military units, many Komsomolites eagerly worked to fulfil these duties. The responsibility and enthusiasm that many Komsomolites displayed at this time would become, by the end of the war, antithetical to the strict control which the Party wanted to exercise over all members of the League involved in the military.

Komsomol members, upon the recommendation of the cell's committee, also participated in the urban and military activities of the widely feared Cheka, Soviet Russia's secret police. Recruited to help fight sabotage, counterrevolution, and war profiteering, enlistment in the Cheka 
gave Komsomolites the freedom to instil terror in the population. In Petrograd and Moscow Komsomol Chekists often received orders to round up suspected spies and white guard sympathizers. This order essentially gave them carte blanche to harass and imprison whomever they wanted. ${ }^{23}$ One unfortunate outcome of unbridled power was the habit of Komsomol Chekists to coerce people to join military detachments. ${ }^{24}$ Despite such acts, Komsomol Chekists also performed benevolent duties. Endowed with special powers and authority, Komsomol Chekists could force war speculators to lower prices on precious goods so that people could afford to buy them. This action was intended to ease tensions in the cities and foster support for the Bolsheviks.

In the military sphere Komsomol Chekists were present to prevent soldiers from evading their duties and to supervise the actions of the important military horse regiments and armoured car divisions. The fear of Soviet justice that they instilled in soldiers promoted valour and patriotism at the front. One of the Chekists' most important jobs in the prefront areas was to round up people suspected of helping the enemy or of holding the wrong political sympathies. The suppression of counterespionage was deemed essential if fifth column activities were to be brought under control. Following the war the Komsomol continued to participate in Cheka operations, including the 1921 attack on the Kronstadt naval base. During this assault experienced Party agitators closely supervised Komsomol Chekists. ${ }^{25}$

Much of the Komsomol's work in the Civil War was devored to partisan activities in territory held by the enemy. In an effort to undermine the authority of the Whites, Bolshevik agitators ordered Komsomol members from cells in Soviet-held territory adjacent to the front to establish illegal Komsomol organizations immediately behind enemy lines. Successfully organized conspiratorial groups were formed in the areas of the Ukraine around Kiev and Kharkov, and in the port city of Odessa. The underground Komsomol organization in Odessa held its conference every three days. Members discussed the printing and distribution 
of banned literature, the expansion of the organization, the collection of information on enemy activities, and the storage of guns and ammunition in preparation for the advance of Red Army soldiers. ${ }^{26}$ All these activities were extremely dangerous, as the White armies showed little mercy to Soviet supporters, but they afforded Komsomol members the opportunity to prove their political convictions and support the revolution in an atmosphere which rewarded independent initiarive.

In rural areas occupied by White armies, Komsomol members attempted to disrupt the enemy's lines of communication by destroying bridges, railway and telegraph lines, and by reporting to Red Army intelligence on the movements of White Army divisions. They also tried to attract new members from occupied territories by informing people about the White terror, distriburing Bolshevik papers and leaflets, and discrediting enemy youth organizations such as the Ukrainian Workers' Communist Union of Youth. With underground activities extending throughout Ukraine, Byelorussia, the Caucasus, and Siberia, the partisan activities of Komsomol members were extensive. The self-reliant and responsible temperament that such work fostered would, with the defeat of the Whites, prove undesirable as the Party now wished to inhibit the independence of Komsomol recruits. The Bolshevik's success in the Civil War afforded them the opportunity to impose this mandate on the Komsomol.

The Party's attempts to curtail Komsomol independence began immediately following the Bolshevik victory in the Civil War. For their work in partisan groups and in regular military divisions, some of which were composed entirely of Komsomol members, the Party rewarded over five thousand Komsomolites with the order of the Red Banner. ${ }^{27}$ Many Komsomol members believed that proper recognition of their military contribution and support of the Bolsheviks should have warranted the establishment of Komsomol cells in military units. This feeling was so widespread and the desire for true Komsomol independence 
so popular that many Komsomolites had, by the end of the war, already established cells in their units. In an attempt to curtail Komsomol independence in the military the Party refused to sanction the creation of these rogue military Komsomol cells and told Komsomol members to subordinate themselves to military Party organs. To bolster its position the Party ordered the Komsomol Central Committee to force its members to comply with this directive.

Following a lively debate at the Second Komsomol Congress in 1919, the Central Committee reluctanty concurred with the Party's decision and voted 120 to 94 that Komsomolites be required to register as candidate members of military Party organs. ${ }^{28}$ This surprisingly narrow majority showed the Party that many members of the League's leadership wanted greater power over Komsomol military recruits. The Komsomol's defiance of Party wishes was mollified only after $\mathrm{E}$. Tsetlin, a young Bolshevik who was influential in the establishment of the League, told members that the creation of Komsomol cells would lead to dual authority and separatism in military units and threaten the integrity of the armed forces. This plea successfully persuaded the Komsomol Central Committee to disband all military Komsomol cells. ${ }^{29}$ The Bolsheviks, however, were still convinced that the League posed a threat to Party authority in the military. They therefore resolved to undertake stringent measures to deal with the perceived danger of Komsomol autonomy in the military.

In November 1921 the Party charged a commission consisting of members from the Party Central Committee, the Revolutionary Military Council, the Political Administration of the Red Army, and the Komsomol Central Committee to examine the problem of supervision over Komsomol military recruits. After careful review the committee advised that the best way to maincain control over Komsomolites in the military would be to forbid the creation of Komsomol cells while forcibly inducting Komsomolites into Party cells as candidare members. When this report was placed before the Party, the Central Committee accepted the 
recommendation against the creation of military cells but refused to allow the automatic induction of Komsomol members into the Party. The Bolshevik leadership believed that such an action would lower the political reliability of Party cadres by flooding the Party with many untested and unreliable Komsomolites. ${ }^{30}$

Retaining the status quo, however, would satisfy neither the Party, which still did not exercise complete authority over Komsomol recruits, nor the Komsomol, which had been debating the position of its members in the military at the Third Komsomol Congress in 1920. In 1921 the Party finally adopted two measures which would simultaneously satisfy the requests of the Komsomol to address the condition of its members and enhance Party control over Komsomol recruits. In October, the Party granted the Komsomol patronage of the Navy, and in December, it permitted Komsomol cells in militaryeducational institutions. While both measures would deflect criticism that the Party was mistreating military Komsomol members, they would more importantly channel the energies of the youths into activities that would benefit the Party and strengthen Party control over the military.

The Komsomol began its patronage duties by enlisting 2,000 of its members into naval work in February 1922, increasing this number to 8,000 by the end of the year. Their immediate task was to repair ships and barracks which had been damaged during the Civil War. Since the complete rebuilding of Soviet Russia's naval forces was very important to the Party, the Central Committee instructed district Party committees to aid the Komsomol's mobilization. It accomplished this task by helping select Komsomol members to lead enlistment efforts and ensuring transport so that the recruitment ran on schedule. ${ }^{31}$ Coordination and leadership of the Komsomol's patronage work were hence solely the prerogative of the Party.

The work demanded of naval Komsomol workers was very mentally taxing and so the Party recruited only "literate, physically strong, politically mature factory workers with 
length of service in the Komsomol of not less than one year. ${ }^{32}$ Since between 70 and 80 percent of the Komsomol members recruited for naval patronage duties were industrial workers, it is clear that the Party intended to concentrate Komsomol work on repairing ships and dockyards. ${ }^{33}$ To ensure the political reliability of the remaining 20 to 30 percent of Komsomolites, the Komsomol Central Committee decided that peasants were to have been in the ranks of the Komsomol for nor less than one year and any others for at least a year and a half. ${ }^{34}$ The task of supervising peasant recruits by having them work with their urban counterparts grew in importance as rural members began to overwhelm the League's membership.

In 1922 and 1923, the Komsomol leadership expanded its patronage duties in the navy by instructing district and provincial Komsomol organizations to affiliate themselves to various fleets. As a result, twenty-five primary Komsomol organizations were attached to the Baltic Fleet, twenty to the Black Sea Fleet, and six to the Caspian Sea Fleet. ${ }^{35}$ The Komsomol organizations were responsible for accelerating the rebuilding of the respective fleets and therefore members organized subbotniki and voskresniki as well as concerts and stage productions to earn money for navy funds. Komsomol members in factories, who were encouraged to "donate" part of their monthly earnings for the rebuilding of the navy, also contribured to these funds. The influence of urban workers in the navy would grow over time to the point where socialist competitions and shock worker brigades would be used in an attempt to raise the educational and disciplinary levels in the military. ${ }^{36}$ Once again, urban workers, who were more trusted by the Party than those from the countryside, were used to indoctrinate and supervise the actions of rural members in an effort to proletarianize them and transform them into Bolshevik supporters.

Education was a very important element in the patronage program of the Komsomol. In February 1924, the Komsomol began to replenish the students at the Naval Educational Facilities (NEF). At these institutions students 
received a general military education including political subjects such as the History of the Party and the Russian Navy, and pracrical subjects such as naval signals and Morse code. ${ }^{37}$ Local Komsomol committees chose NEF candidates, who were usually industrial workers, according to assessments laid out by the Party Central Committee. A committee consisting of Party and Komsomol members, and representatives of the Navy, then examined the candidates on the basis of health, general education, and political preparation. The committee thereafter sent successful applicants to the school where the final decision on entrance would be made. ${ }^{38}$ As a result of this process naval educacional facilities recruited only politically reliable and physically fit Komsomolites. The Party told graduates of these facilities to lead by example, and required them to promore political education, military discipline and education, and mastery of weaponry.

Inside the closed environment of these institutions Party organizations could easily maintain tight control over Komsomol recruits, who, as illustrated above, were closely screened for their political reliability and social background. For this reason the Party considered that the creation of Komsomol cells would not pose a threat to strict Party control of the students. Cells were established with a minimum of three Komsomol members and all Party members under the age of twenty were also instructed to enter. Within one year of their organization over 120 cells with 10,000 Komsomol members had been formed. ${ }^{39}$

Military training and political indoctrination courses ranged from three ro four years of study, depending upon the specific area the student was studying. All students were required to study Marxism-Leninism, the History of the Civil War, and pedagogy, as well as strategy, tactics, and military economics and history. The specific duties of Komsomol cells ranged from promoting political indoctrination to tightening discipline. Although Komsomol cells were required to coordinate their work with Party cells and were fully subordinated to them ${ }^{40}$ they were still able to elect 
their own buroand administer the work of the cell, provided, however, that there were ten or more members in the cell. ${ }^{41}$ This limited autonomy still lent itself to Party control of Komsomol recruits, as Party members regularly supervised these politically mature Komsomol members.

In spite of the successful work of Komsomol cells in military educational institutions and the continual political indoctrination of peasant recruits, by 1923 the Party still would not condone the creation of cells in military units. A Party Central Committee order issued in February declared that all educational work among military Komsomol members would continue under the leadership of Party political organs. The Party also retained the prerogative ro decide on the entrance to and exclusion from the Komsomol withour having to confer with local Komsomol authorities ${ }^{42}$ and had the right to choose a Party member who would organize the work of League members. This coordinator was responsible for the administration and fulfilment of all Komsomol activities and duties in the respective military unit.

One aspect of the February resolution that differed from the 1921 ban on military Komsomol cells was the requirement that all Komsomolites had to register in both the local Komsomol organization, from which they would receive their Komsomol card, and in the military Party organization. ${ }^{43}$ Because membership in the Party would mean that Komsomol members were obliged to attend open Party meetings and fulfil Party decisions, but only with the right to a deliberative vote, this measure was probably taken to control further the rapidly growing number of Komsomol recruits. Because most Komsomol conscripts were now recruited solely from the peasantry and had received minimal political education compared to their counterparts in military educational institutions, forcing them to maintain Party discipline would be one way of assuming direct control over them.

To raise the political level of Komsomol soldiers, Party workers forced Komsomolites to attend political education classes and discussions, and to spend time in the divisional 
library reading books on Marx and Lenin. By late 1923 the political curriculum also included anti-Trotsky propaganda which was intended to unseat the founder of the Red Army from his base of support in the military. ${ }^{44}$ Although the political indoctrination of recruits was comprehensive, it was a never-ending process as the Komsomol ranks were continually replenished with new members. By 1924 the number of Komsomolites in the military rose to over 30,000, all of whom, in accordance with the February 1923 resolution, were obliged to enter military Party organs.

The rapid influx of raw peasant recruits could not but have a detrimental effect on both the Komsomolites' training and on the political elitism of military Party organs. A purge of the Komsomol members from Party organs would remedy the problem of dilured Party ranks. Simply removing Komsomol members from Party organs would, however, be a return to the situation of 1921 , which was unworkable given the rapid growth in Komsomol membership. The Party, therefore, decided on a compromise solution: Komsomol members would be eliminated from Party lists and allowed to form special groups which would facilitate Komsomol training but would be totally under the control of the Party.

The first step toward the creation of special sections of the Komsomol came in mid-1924 at a Party conference of the Leningrad Military District. The conference members concluded that Party military cells did not devote sufficient attention to the work of Komsomol conscripts and that the existing organizational structure for Komsomol members in the military had become ourdated. Party conferences in the Northern Caucasus and Siberian Military Districts supported this conclusion. ${ }^{45}$ On the advice of these conferences the Party Central Committee decided upon the creation of Komsomol "groups assisting the Party" in August 1924.

After consultations with the Military Political Administration the Party worked out the framework of these groups. Komsomol members would be dropped from Party lists and obliged to enter these groups, which would not be 
permitted their own elected organs and had to work under strict Party leadership. ${ }^{40}$ This move to restrict the access of Komsomol members into the Party was further entrenched in May 1925 when the Military Political Administration, rogether with the Komsomol Central Committee, decided that the upper age limit on Komsomol membership be raised from 23 to 24 years to accommodare those elder Komsomolites who were refused entrance into the Party ${ }^{47}$ During this extra year in the ranks of the League, members could receive additional political training, thereby making their application for entrance into the Party more attractive. This move came at a crucial time since by July 1925 there were more than 78,400 Komsomolites in the army and navy, which was more than twice the number of the previous year and also more than the number of Party members. ${ }^{48}$

In July 1925, the Military Political Administration and the Komsomol Central Committee further outlined the organization of the Komsomol groups. Their first and most important point was that military Party organs had unconditional leadership over these bodies. Komsomol members were still required to participate in Party meetings and work and fulfil all Party decisions, including all political education and enlightenment classes and programs. A Komsomol organizer and a Parry member were responsible for arranging the daily work of the cell. Also, although entrance and exclusion from the groups could be discussed at a group meeting, Party organs had first to approve members before they could be admitted. Finally, a Party commission and the local Komsomol committee had to accept applicants who wished to join the Party following their time in the Komsomol. Since all these stipulations, except the last one, were required of Komsomolites when they were candidate members of the Party, the formation of "groups assisting the Party" had effectively cleansed the Party of Komsomol members while still maintaining strict Party control over them.

From their dealings with the revolurionary student movement to their creation of "groups assisting the Party," 
the Bolsheviks were motivated by their desire to control Russia's youths. In spite of the admirable performance and proven loyalty of Komsomolites during the war, the Bolsheviks refused the requests for greater autonomy that were enunciared at the Second and Third Komsomol Congresses. Had the Party been able to control military units as effectively as it controlled the NEF, the Bolsheviks may have assented to the Komsomol's requests. But, because they were unwilling to allow greater Komsomol autonomy, the Bolsheviks were finally forced to establish "groups assisting the Party." Since neither the Komsomol nor the Party was concent with the power the other exercised over Komsomol recruits, the struggle for control over them would continue to characterize Party-Komsomol relations in the Soviet military. 
Party-Komsomol Relations 21

\section{NOTES}

'The original name of the organization, the Russian Communist Youth League (RKSM), was chosen by the delegates at the First Komsomol Congress in order to show their allegiance to the Russian Communist Party (b). At the Sixth Komsomol Congress in 1924 the name was modified to the Russian Leninist Communist Youth League (RLKSM) and in 1926 the final name of the All-Union Leninist Communist Youth League (VLKSM) was adopted.

${ }^{2}$ One of the first documents that the Komsomol Central Committee, which had been stacked with Bolshevik supporters, ratified was: "On the Interrelationship between the Russian Communist Youth League and the Russian Communist Party (b)." The directives in this document fully subordinated Komsomol members to orders from the Party. Full control of Komsomol cells by the Party was not continuously achieved in all spheres of sociery, especially in the countryside where rural members continually disregarded orders from Moscow. In the military, however, control of cells was noticeably tighter since the Party could not risk the insubordination of well-armed troops. See $L$. Antipina, ed., KPSS okomsomole i molodezhi shomik rezoliutsii $i$ reshenii s"ezdov, konferentsii TsK 1917-1958 (Moscow, 1958), 33-34.

'The Komsomol, which was structured in the same way as the Party, had cells at the local, district, provincial, territorial, and state levels. The members who were most defiant of the Party were usually at the local level while those in the Komsomol Central Committee were the most conciliatory.

${ }^{4}$ General studies of the Komsomol by Western academics have been negligent in examining the Party imposed directives of the League. Klaus Mehnert's book Youth in Soviet Russia (London, 1933), while ground-breaking, is limited to a narration of the author's experiences in the Soviet Union. Merle Fainsod, in How Russia is Ruled (Cambridge, Mass., 1953) and Smolensk under Soviet Rule (Cambridge. Mass., 1958) builds upon Mehnert's work by tackling the topic of the political manipulation of youths. In his discussion of the Komsomol, Fainsod outlines the organizational structure, history, and regulations of the League. These same subjects are dealt with, albeit in greater detail, by Ralph T. Fisher in his book Pattern for Soviet Youth: A Study of the Congresses of the Komsomol, 1918-1954 (New York, 1959). Focusing on the high level political work of the organization. Fisher's book neglects the grass-roots work of the League. These early studies were followed by a few mediocre works whose authors concentrated on the same topics as their predecessors. 
'Since the Komsomol had already organized cells in industrial enterprises and the countryside, the prohibition against their creation in military units was widely protested by the league.

'Yu.P. Petrov, Partiinoe stroitel stuo y souetskoi armis i flote (1918-1961 gg.) (Moscow, 1964), 250

"G. Solonitsyn, "Komsomol na strazhe rodiny," Voenno-istoricheskii zhurnal 10 (1968) and Alexander Khmcl, Education of the Soviet Soldier (Moscow, 1972), are two examples of Party propaganda replacing scholarship.

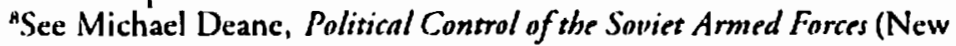
York, 1977); Zbigniew Brzezinski, ed.. Political Controls in the Soviet Army (New York, 1954); and Timothy Colton, Commissars. Commanders. and Civilian Authority (Cambridge. Mass., 1979). The most comprehensive study of the Komsomol in the contemporary Soviet milicary is Sergei Zamascikov's monograph Political Organizations in the Souiet Armed Forces-The Role of the Party and the Komsomol (Falls Church Va., 1982).

'Mark von Hagen's book Soldiers in the Proletarian Dictatorship: The Red Army and the Soniet Socinlist State, 1917-1930 (London, 1990) focuses on the early political relationship between the Party and the military.

${ }^{10}$ Unfortunately, Soviet document collections, such as V. Kolosov, ed.. Touarishch Komsomal (Moscow, 1969), I. Kravstov, ed., KPSS o podgotonke molodezhik voennoi sluzhbe (Moscow, 1985), and P. Sharpilo. ed., Partiino-politicheskain rabota "krasnoi armii (Moscow, 1964) as well as his KPSS o vooruzhennykh silakh snyetskogo soiuza (Moscow. 1969), offer little information on early Party-Komsomol relations and on the particular role of the League in the military. The League's newspaper, Komsomol'skain prauda, which began publication in 1925. has also offered little information on the topic.

"A. Shokhin, Kratkaia istoriia VLKSM (Moscow, 1928), 74. The remaining six mobilizations were the special mobilization for political departments of the Tenth Army, May 1919; recruitment for the formation of privileged companies; mobilization for the defence of Petrograd, October 1919; mobilization of Ukrainian Komsomolites for the Wrangel front; first mobilization for command courses, Summer 1920; and second mobilization for command courses, Spring 1921.

${ }^{12}$ In an effort to combat the growing rate of desertion from the Red Army the military political administration, in May 1920, issued a ninepoint order on the measures to be used to combat noncompliance. See Sharpilo, Partiino. 88-89.

${ }^{13}$ Shokhin, Kratkaia istoriia VLKSM. 71

14Antipina, KPSS o komsomole. 35 
"See Shokhin, Kratknin istoriia VLKSM,73-74; A. Kamshalov, I.eninskii komsomol (Moscow, 1969), 223; and B. Pastukhov, Slnunii put' Leninskogo komsomola (Moscow, 1978), 93.

"Shokhin. Krntkain istoriin VLKSM. 75

'Kamshalov, Leninskii komsomol 214

18Ibid., 224

"M. Savinskii, "Zarozhdenie bibliotechnogo dela v krasnoi armii (1918-1920 gg.)," Voenno-istoricheskii zhurnal 3 (1977), 96

${ }^{20}$ Kamshalov, Leninskii komsomoh 240

${ }^{21}$ In chapter 17 of Smolensk under Soviet Rule Fainsod illustrates the difficulties experienced by soldiers' families in the 1930s and the disintesest of the military bureaucracy in their maintenance. lixcept for the frequent use of soldiers in gathering the harvest, the military wished to widen the breach between soldiers, most of whom were peasants, and their families in the countryside. For a better understanding of the Party's policies in the countryside see Moshe Lewin, Russian Pensants and Soviet Power(Evanston. III., 1968) and Naum Jasny. The Socialized Agriculture of the USSR Plans and Performance (Stanford. Cal.. 1949). ${ }^{22}$ Yu. Dzagurova ct al., "Komsomol v gody grazhdanskoi voiny," Voenno-istoricheskii zhumal 10 (1968), $91-92$

2.Kamshalov, Leninskii komsomoh 281

${ }^{24} \mathrm{~N}$. Shalaginov, "Uchastic Viatskikh komsomol'stev $v$ bor'be $s$ Kolchakom," Voenno-istoricheskii zhumal 5 (1972), 81

"s. Dilanian, "Komsomol'tsy-chekisty v boiakh za rodinu," Voennoistoricheskii abumal 12 (1968), 108

${ }^{26}$ Kamshalov, Leninskii komsomol, 254

${ }^{27}$ G.V. Vorontsov, ed.. Partiinoe rukovodstvo komsomolom (Leningrad, 1981), 117

${ }^{28} Y$ Y.P. Petrov, Stroitel'stun politonganov. partiinykh i komsomol'skikh onganizatsii armii i flotn (1918-1968) (Moscow, 1968), 76

${ }^{29}$ Fisher, Pattern for Soviet Youth, 49

".yu.P. Petrov, Partiinoe, (Moscow, 1964), 246-247. During the Civil War many of the League's urban members died and the Komsomol became a predominantly rural organization. Believing that only industrial workers were allies of the Bolsheviks the Party viewed the Komsomol with misgivings. See von Hagen's Soldiers in the Proletarian Dictatorship for information on the peasantry's loathing of the Bolsheviks and how this affected the military.

${ }^{31} \mathrm{~V}$. Nelaev, "Leninskii komsomol-shef flota (1922-1945 gg.)," in Pozyunye istorii uypusk tretii. ed. B. Nikjforov (Moscow, 1973), 192

${ }^{32}$ N. Berezovskii, "Komsomol'skie mobilizatsii v krasnoi flot v 1922 1923 gg," Voenno-istoricheskii zhurnal7 (1983), 78

"'lbid., 79

"S. Efimov, "Komsomol-shef flota," Voenna-istoricheskii zhumal 10 (1972). 71. To prevent the mistrust of the Party which was prevalent 
in the countryside from entering the ranks of the military, the Party insisted that a strong urban presence be created in each unit. This proved to be unsuccessful as the military became more and more manned by peasants. Sec Fainsod, How Russia is Ruled, 402-403.

"Nelacv, "Leninskii komsomol," 195

"G. Zelentsov, "Sotsialisticheskoe sorevnovanie v vooruzhennykh silakh." Voenno-istoricheskii zhumal9 (1973), 74

"Nelaev, "Leninskii komsomol," 196

sP. Golubev, "Leninskii komsomol i podgotovka kadrov dlia voennomorskogo flota SSSR (1922-1941 gg.)." Voenno-istoricheskii zhumal9 (1972), 85

"Petrov, Partionoe stroitel'stro, 247

${ }^{10} \mathrm{~A}$. Jovlev, "Sovershenstvovanie voenno-uchebnykh zavedenii v 1921 1928 gg.," Voenno-istoricheskii zhumal 2 (1976), 96-97

'V. Dement'ev, "Deiatel'nost' KPSS po sozdaniiu i organizatsionnomy urkrepleniiu armeiskogo komsomola," Voenno-istoricheskii zhumal 7 (1968), 4

42V.G. Kurgan, Voprosy partiinoi i komsomol'skoi raboty v savetskoi armii i voenno-morskom flote (Moscow, 1965), 142

4:Petrov, Partiinoe stroitel'stio. 247-248

"Petrov, Partiinoe stroitel'stvo, 161. At the 10th Party Congress in March 1921, a heated debate erupted between Commissar of War Trotsky and M.V. Frunze, who hecame Chief of Staff of the Red Army in March 1924 and People's Commissar for Military Affairs in January 1925. over their opposing military doctrines. With the approval of Stalin a purge of Trotsky supporters, many of whom were political commissars and military specialists, was begun in the military at the start of 1924 and succeeded in removing l' rotsky from his position on January 17, 1925.

"slbid, 248

* M.S. Leonov, Partiinoe-politicheskaia rabotn vsovetskikh vooruzhennykh silakh (Moscow, 1972), 83

"Petrov, Partiinoe stroitel'stua, 250

${ }^{48}$ Ibid., 252 